\title{
Factors influencing loan repayment performance among group borrowers in Bungoma West District, Bungoma County.
}

\author{
${ }^{1}$ Sungwacha Stephen M., ${ }^{2}$ Brian Singoro Wanyama, ${ }^{3}$ Kirathi Mirriam, \\ ${ }^{I}$ Department of Human Resource Management, Jomo Kenyatta University of Science And Technology, 2014. \\ ${ }^{2}$ Department of Business and Economics, Kibabii University Mount Kenya University \\ ${ }^{3}$ Department of Educational Planning
}

\begin{abstract}
Micro financing plays a key role in enabling small business organizations to expand their businesses and fund their operational costs. Micro finance is the supply of microloans, savings; micro insurance and other basic financial services to the poor-particularly those who have been left out by conventional banking institutions. Micro Financial Institutions lend small businesses both short term and long term loans. MFIs have embedded their operations in rural areas with the purpose of alleviating the poverty problem that affects many people. The lending philosophy of MFIs is based on the Grameen Bank model in which social groups form the collateral for receiving a loan. Without legal contractual obligations established to push members to adhere to a stipulated timeframe and interest rates many group members fail to pay back under the lenders' lending conditions. The purpose of this research is to investigate factors influencing loan payment ability of entrepreneurs accessing credit through groups.
\end{abstract}

\section{Introduction}

The success of Grameen Bank of Bangladesh to reach the poor and the marginalized few in the rural areas and raise their status through micro financing has proved that micro financing is a feasible tool for creating economic empowerment among the poor. This success has seen the emergence of financial institution in the financial sector to fill the gap where commercial banks do not venture. Different MFIs operating in various areas have come up with variety financial services tailored to suit borrowers in various economic environments. In general, the average loans are fairly low and the default rate is also very low. Strategies used in risk management include; acceptance of chattel mortgage as part of security requirements, conservative loans classification and ageing criteria. MFIs also strengthen credit departments by recruiting a sizeable number of Micro Credit Officers and seasoned credit managers. Risks are attributable to their loans and advances. They structure the level of credit they undertake by placing limits on amounts of risk accepted in relation to one borrower. Such risks are monitored on a regular basis and are subjected to monthly or more frequent reviews. Risk management strategies include; analysis of the ability of borrowers and potential borrowers to meet interest and principal and repayment obligations, obtaining collateral and corporate guarantee where considered necessary, these institutions have no significant concentration of credit risk, with exposure spread over a diversity of personal and commercial customers. There is also diversity in various sector exposures; there is a comprehensive loan appraisal system, which highly focuses on cash flows. Lending process is guided by branch, head Office, executive and board credit committees with graduated risk limits. Target beneficiaries of these financial institutions are women, small scale business enterprises and the youth who cannot provide adequate collateral to befit from mainstream banks. This is frequently attributed to the lack of property rights in land or to limited ownership of physical or financial assets.

Lending programs by these financial institutions either make use of existing social structures or have formed peer groups through which individual members access credit. Groups ensure appropriate borrower selection and screening. Screening helps in determining the likelihood that a borrower will not default on the loan and provide incentives for the borrowers to repay and enforce repayment. However there are potential problems that lenders continue to face while dealing with group clients. These problems result directly from imperfect information on projects and the credit worthiness of the clients. This may be attributed to distorted information prevalent in rural areas because of market segmentation by village and kinship groups. The weak legal system and the lack of enforcement mechanisms lead to difficulties in monitoring borrowers and obtaining enforcing repayment of loans. Politicization of rural credit; lack of supervision; lack of knowledge about the borrowers' affairs over the lifetime of the loan; lack of technical ability among credit lenders to analyze and evaluate the borrowers and erratic changes in relative prices which affect disposable incomes adversely affect returns on investments. Additionally relative rate of inflation associated with unstable economy would make small scale borrowers vulnerable. They fail to get maximum cash flows from their investments rendering them unable to service their debt credit. 
Joint liability

\section{Literature Review}

Ghatak and Guinnane, (1999) review the key mechanisms proposed by various theories through which joint liability could improve repayment performance rates and the welfare of credit constrained borrowers. They suggest that to alleviate the problems facing borrowers, mechanisms such as _ screening, monitoring, auditing and enforcement can effectively increase repayment. Fischer and Ghatak propose utilizing the local information social capital that exists among borrowers to reduce prevalence of default (Fischer and Ghatak, 2010). Group lending mechanism has several inherent implicit economies. The cost of screening and monitoring for creditors can be low as a result of close familiarity with borrowers. In this case information is easy to get because of living near the borrower or being part of the same group. Members know each others' actions, types, and states than outsiders. Furthermore, social pressure among members of the same group may be high and more efficient means of motivating loan repayment. Consequently many financial institutions apply group lending principles to achieve the advantages of peer groups when extending and recovering credit from clients.

\section{Credit mechanisms}

Literature by Chowdhurry (2005) and Aniket, (2006) highlight sequential lending as an important mechanism which can bolster repayment rates. They point out that loans are not typically given to all borrowers simultaneously_a member gets a loan only after the previous member has paid a number of her installments properly. For example in a two member group, one member gets a loan after the previous member has paid a number of her installments. This creates an additional stake for the member who comes in later to monitor the previous one.

\section{High frequency repayment}

Borrowers are typically required to repay their loans in regular installments, soon after loan disbursements. This aspect of the repayment schedule is usually explained as inducing 'fiscal discipline' among borrowers. Jan and Mansuri (2003) argue that an alternative rationale for this loan structure is reflected in the monitoring of the borrowers actions. The likelihood that a borrower will default pauses a risk which compels MFIs to use innovative mechanisms, which indirectly co opt the better informed informal lenders (Greg Fischer and Ghatak, 2009).High frequent repayment though attracts certain costs. It imposes an opportunity cost of meeting attendance on borrowers and direct costs on the lender. It might also distort the investment incentives of borrowers towards projects that generate consistent if meager returns.(Fischer and Ghatak, 2009)

\section{Credit Camp Meetings}

Group members are required to meet at certain time intervals for group education and loan borrower selection. Rai and Sjostrom, (2004) argue that frequent meetings serve as a means for the lender to extract information about borrowers' projects. Such information helps the lender to screen potential borrowers and determine if a defaulter is strategic or if a borrower genuinely cannot repay. Group meetings are a forum in which sanctions are put on members to repay their loans and give chance to next applicants to get credit. Group meetings have proved to strengthen trust, cohesiveness and seriousness of a member (Adams, 1992). There are other repayment strategies meant to accelerate repayment proposed by Field and Pande ,(2008); Fischer and Ghatak,(2009).

\section{Gender and politics}

As observed by ILO, women may simply be used as low cost and reliable intermediaries between loan program staff and male family members. Women may not have a say or even an effective use of the loan. Male dominant influence will sway the loan use to their side augmenting allocation risks and misappropriation. Where the client is a woman and has no control over the returns from a family enterprise such a borrower may be disillusioned and less enthusiastic to work hard to recoup resources to pay back (Linda Mayaux,1998).The political environment influences repayment performance. A study in India by The Agricultural Credit Committee, (1999) noted that during the election years there is a lot of propaganda from the political platform for postponement of loan recovery or pressure on the credit institutions to grant extensions to avoid or delay the enforcement process of recovery. The political environment creates 'willful defaulters' who are generally socially and politically important people whose example other members in the group model. Julian et al,( 1996), argue that influential members create a 'negative domino effect' which influences good payers to model their behavior.

\section{Methedology And Data}

The paper examines factors influencing loan repayment performance gy group borrowers in Bungoma West District, Bungoma County in Kenya. The study area has a diverse clientele of group borrowers :animal 
vendors groups, youth groups, women groups and small business enterprises .These groups lack property rights like land title deeds which can act as collateral for commercial banks. They revert to group borrowing through social homogeneous groups. The diversity of these groups is significant because it presents various loan environments that influence repayment performance. The area has both urban and rural clients. Sirisia and Malakisi areas are typically urban with several borrowers running small businesses. Machakha, Lwakhakha and Butonge are inhabited by rural clients who predominantly invest in peasant farming. Factors studied in this research included i) gender ii) participation in group credit camps iii) meetings by borrowers iv) loss resulting from business operations v) multiple loans from other financiers vi) and vi) frequent loan repayment schedule. A survey questionnaire was used to collect data from 20 randomly selected groups from the population. Questions were framed to reduce continuous variables to binary variables capturing the perceptions of respondent group members (Appendix ii).As noted by Julian Anne,(1996) group members are reticent about answering questions pertaining to individual wealth, informal sources of credit and group leaders decline answering questions on repayment problems members face in their groups. The question on the frequency of attending group meetings is significant because many group members have busy schedules, there is need to establish how they match group meetings with their business activities.

There are several models that have been developed to analyze determinants of repayment performance by group borrowers. The Besley and Coate model for group lending has extensively been used by Julian Anne et al,( 1996),to determine factors that influence repayment performance of group borrowers in Burkina Faso. The model incorporates various determinants that influence loan repayment and aptly demonstrates influences of each factor. Influences that increase the probability of loan repayment include effective use of group dynamics with peer pressure before and after the loan being given greater attention (Julia Anne et al(1996) . This is a repayment game model which is open ended and incorporates various determinants: age, gender, location of the borrower ,income of the borrower, level of education and other variables that influence repayment. The repayment game includes two homogeneous borrowers who earn a return $\Theta$ on their project, depending on a random probability distribution. The individuals each pay back the unit plus interest at the end of the period(r).They can encourage each other to repay by inflicting social sanctions (s) against one another in the case of arrears. Finally the bank can charge penalties (p) for arrears by confiscating property or by hassling recalcitrant borrowers. From their project returns each individual decides to contribute (c) or not to contribute (n).In the case that one individual pays and the other does not $(\mathrm{c}, \mathrm{n})$, the repaying member decides whether or not to repay, for both or to default (D).There are two possible outcomes from the game :it is possible to have group solidarity (helping a member who cannot / will not repay to maintain correct repayment.Secondly the domino effect can occur when an individual who independently would repay the loan decides to default on the other member.

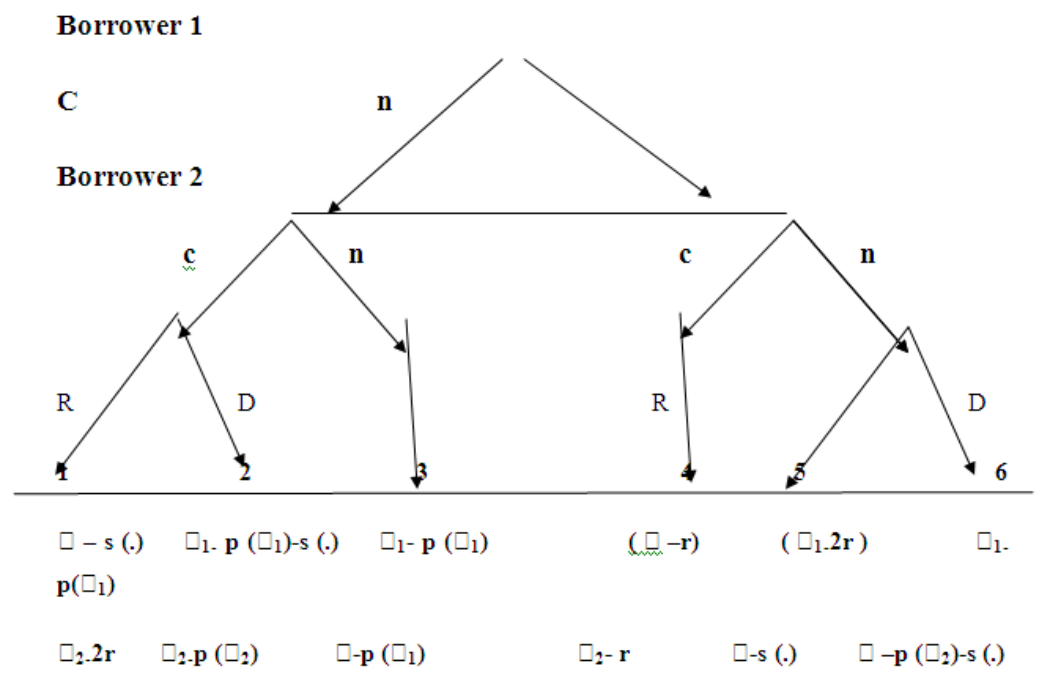

N.B when the strategy is $\left\{\mathbf{n},(\mathbf{c}, \mathbf{R}), \mathbf{s}()=.\mathbf{s}(\mathbf{r}, \boldsymbol{\theta}\}\right.$, when it is $\{(\mathbf{c}, \mathbf{R}), \mathbf{n}\}, \mathbf{s}()=.\mathbf{s}\left(\mathbf{r}, \boldsymbol{\theta}_{2}\right)$, when it is $\{(\mathbf{c}, \mathbf{D})\},, \mathbf{s}()=.\mathbf{s}\left(\mathbf{p}\left(\boldsymbol{\theta}_{2}\right)-\mathbf{r} \boldsymbol{\theta}_{1}\right)$ when it is $\{(\mathbf{c}, \mathbf{D}), \mathbf{n}\}, \mathbf{s}()=.\mathbf{s}\left(\mathbf{p}\left(\boldsymbol{\theta}_{1}\right)-\mathbf{r}, \boldsymbol{\theta}_{2}\right)$

FIG1. Besley and Coate repayment Game, (1993).

\section{Analytical methods}

Much as the Besley and Coate model simplifies the understanding of repayment dynamics, it lacks inbuilt econometric tools of analysis to accurately analyze individual variable's marginal influence on repayment performance. Secondly the model is has not been tested with empirical evidence,(Julia Anne,1996 pg 
21).Econometric models of linear and non-linear regression-the probit, logit and tobit are used to further give possible results of the game models and derive interpretations. This research employed two limit tobit regression model to determine causes of loan repayment in Bungoma West District. The tobit model developed by James Tobin and explained by Maddala,(2001). Using Milton Sileshi et al,(2012) approach. The value of the dependent variable Y (regressand) is repayment ratio that is computed as the ratio of amount of loan repaid to the total amount due from creditors. The effect of unit change in determinants on the probability that $\mathrm{Y}=1$ (that a borrower) will pay can be computed using the derivative of $\mathrm{Y}$ with respect $\mathrm{X}$.

$\mathrm{Y}=\beta_{1}+\beta_{2} \mathrm{Xi}+\mathrm{Ui}$

$\partial y=f\left(\beta_{1}+\beta_{2} X i\right) \beta_{2}$

For a large number of $\mathrm{X}$ variables the chain rule is employed to give the rate of change of the probability of $\mathrm{Y}$ with respect to $\mathrm{X}$.

$\partial \mathrm{y} i=\partial \mathrm{f}(\mathrm{x}) \cdot \partial \mathrm{x}$
$\partial \mathrm{x}_{1}$
$\partial \mathrm{x}$ (iii)

Where $\quad \mathrm{x}=\beta_{1}+\beta_{2} \mathrm{Xi}$.

$\mathrm{Y}=$ dependent observable variable

$\mathrm{f}\left(\beta_{1}+\beta_{2} \mathrm{Xi}\right)=$ standard normal probability density function estimated at $\beta_{1}+\beta_{2} \mathrm{Xi}$.

$\mathrm{X}_{0}=$ proximity to MFIs (closeness to MFI dummy near $=1 ;$ far away $=0$ )

$\mathrm{X}_{1}=$ participation in credit camps (meeting dummy; participation $=1,0$ otherwise)

$\mathrm{X}_{2}=$ gender (sex dummy; male $=1,0$ otherwise).

$\mathrm{X}_{3}=$ frequent loan repayment (loan amortization dummy; yes $=1,0$ otherwise)

$\mathrm{X}_{4}=$ politics (political influence dummy; yes $=1$; otherwise $=0$ )

The repayment performance of borrowers was regressed on the four hypothesized explanatory variables . The direction of change in the performance of the borrower is indicated by the sign of the coefficients of the explanatory variables.(Maddala, 1985)

IV. Results

\begin{tabular}{|c|c|c|c|c|}
\hline variable & coefficients & t value & p value & Standard error \\
\hline Intercept & 0.16753 & 0.3188 & 0.76 & 0.1675 \\
\hline Proximity to MFIs & $\mathbf{0}$ & 65535 & $\mathbf{0}$ & 0 \\
\hline $\begin{array}{l}\text { Participation in credit } \\
\text { meetings }\end{array}$ & 0.9791 & 2.2 & 0.0791 & 0.44504 \\
\hline Gender & 0.3627 & 0.8354 & 0.1442 & 0.4342 \\
\hline $\begin{array}{l}\text { Strict loan repayment } \\
\text { schedule }\end{array}$ & -0.983 & -2.3613 & 0.0646 & 0.4163 \\
\hline $\begin{array}{lll}\begin{array}{l}\text { Politics } \\
\text { repayment }\end{array} & \text { and } & \text { loan } \\
\end{array}$ & -0.0221 & -0.0481 & 0.9635 & 0.4597 \\
\hline
\end{tabular}

The proximity of the borrower to the MFI (distance, location etc) needs a special mention. The results show that this variable has no significant influence on loan repayment performance with low coefficient values. This should be interpreted incorporating in the analysis two recent strategies by MFIs on loan distribution and repayment .Mobile banking and M-PESA- an online money transfer technology on mobile phones in Kenya has minimized traveling and delays in loan repayment remittance. Easy money transfer is a convenient strategy which serves well far flung borrowers in rural areas particularly Machakha and Lwakhakha with a poor road network. Secondly busy clients like animal vendors and peasant farmers can remit their repayment installments with ease.

The variable of participation by borrowers in credit education meetings has a significant effect loan repayment performance in this research.An increase in attendance by one meeting improves repayment by 0.98. Borrowers participation in group meetings prior to credit sanctioning increases the likelihood of repayment. The probability that a borrower will improve on loan repayment is 91 percent with t-static of 2.2 and p-value of .835 which are quite significant. Such meetings are vital in several ways. Members get an opportunity to evaluate their projects' viability before they are lent money; group leaders use these meetings to emphasize on the need to respect the terms of credit. Finally members are trained on basic financial management skills of financial resources allocation and bookkeeping reducing moral hazards. This enhances loan discipline and improves recovery. 
The dummy on gender shows a better performance on loan repayment by women than men with a coefficient of $.368,70$ percent of female respondents interviewed answering in the affirmative that they have a strong commitment to servicing their loans. Regression analysis shows that a female borrower is likely to improve loan repayment by 36.5 percent. However the probability that one will not default is 19.72 percent. Studies have shown that women borrowers are keener on project selection and focus more on single projects than their male counterparts.

A strict loan repayment schedule is significant on loan repayment. A unit change in the loan amortization schedule decreased default by 98 percent with the probability that a borrower will not default at 91 percent. It has t- static of -2.36 and $0.0646 \mathrm{p}$ - value. Strict loan repayment schedules compel members to repay on time because defaulting attracts penalties. Group members are denied future loans; or an interest is paid on the outstanding principal amount by the borrower; or members' property is confiscated. Alternatively group members are compelled by the financing institution to repay for the defaulter. Many group members work hard to meet the loan repayment datelines to avoid the outlined embarrassment.

The last hypothesized explanatory variable is politics and the political environment on group loan repayment. Regression analysis shows that an increase in politics by one unit decreases repayment by 0.022 with a $\mathrm{t}$ - static of -0.048 , a p-value of 0.964 . The probability that a borrower will perform poorly is 1.23 percent. The political environment is significant as politicians sometimes promise to repay loans on behalf of their supporters, secondly, borrowers who accept such promises influence others and create a negative domino effect which other group members copy. This retards repayment of loans.

\section{Conclusions and recommendations}

The results in this research reflect the various environments in which loan repayment performance may be retarded. Proximity of borrowers to an MFI is not significant on repayment given that banking strategies like mobile services and electronic money transfer technologies adapted by MFIs mitigate travelling challenges. Consequently to increase accessibility MFIs should increase these services. Group meetings prior to loan disbursement is important for members as such forums enhance discipline in members. MFIs should schedule group meetings and utilize them to enlighten borrowers on sound financial practices. Politics pose a risk as it discourages loan repayment as some members influence peers not to repay. Influential group members who heed politicians' advice create a domino effect among others who model their behavior.

\section{References}

[1]. Armenderiz B. and J. Morduch (2002), "The Economics of Microfinance."

[2]. Charles Mensah (2013). "The relationship between loan default and repayment schedule in micro finance institutions in Ghana.

[3]. Greg Fischer (2010), Spanning the chasm: ' Uniting theory and Empirics in microfinance research'.

[4]. Hulme,D.(2000) "Impact assessment methodologies for microfinance: Theory, experience and better practice."

[5]. Navajas ,S et al.(2002) 'Microcredit and the Poorest of the Poor :Theory and Evidence from Bolivia ,'The Triangle of microfinance".

[6]. Rutherford,S. The Poor and their money "Caste and credit Cooperatives in Andra Pradesh, India" Kennedy School of Government Working Paper, September 2006.

[7]. Sungwacha S.M,(2008) "Factors influencing repayment performance of loans among group borrowers". Unpublished work, Kenyatta University repository. 